\title{
Joseph's Food Politics as Life-Keeper of Many People: A Close Rereading of Genesis 47:13-26
}

\author{
Yonky Karman (ㄹ \\ Sekolah Tinggi Filsafat Theologi Jakarta, Indonesia \\ yonky.karman@stftjakarta.ac.id
}

\begin{abstract}
The Septuagint reading predominantly influences the interpretation of Genesis 47:13-26 (primarily v. 21). Despite a positive portrayal of Joseph, he is also seen as Pharaoh's accomplice to enslave the Egyptian people. This connection with slavery activities contradicts the traditional image of Joseph as the life-keeper of many people. Solution for the negative portrait of Joseph usually refers to the Masoretic Text, although it is not a reference to many modern Bible translations and commentaries. The Septuagint as a reference, in this case, is indeed difficult to reject. However, that does not mean that Joseph promotes the slavery of the Egyptian people throughout the land, but rather an ancient form of state capitalism. This article draws on textual criticism, word studies, form criticism, and agricultural knowledge background in the ancient Middle East. The contribution of this research is to show that, instead of enslaving, Joseph formulated an Egyptian food politics in the larger context of Joseph's narrative reality as the life-keeper of many people.
\end{abstract}

\section{Research Highlights}

- This research draws on textual criticism, word studies, form criticism, and agricultural knowledge background in the ancient Middle East.

- According to the broader Genesis's theological context, this study demonstrates that Joseph developed Egyptian agricultural policy within his narrative context as the custodian of many people's lives.

- The author proposes the rereading and translating of Genesis 47:21 which avoids unnecessary ambiguity of interpretation.
Article history

Submitted 15 March 2021

Revised 20 September 2021

Accepted 27 September 2021

\section{Keywords}

slavery; Joseph; food politics; life-keeper; Egypt;

famine; profit sharing

\section{(C) 2021 by author.}

Licensee Veritas: Jurnal Teologi dan Pelayanan.

This article is licensed under the term of the Creative

Commons Attribution-

NonCommercial-ShareAlike 4.0 International

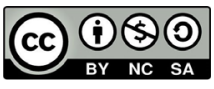




\title{
Politik Pangan Yusuf sebagai Pemelihara Hidup Orang Banyak: Pembacaan Ulang terhadap Kejadian 47:13-26
}

\author{
Yonky Karman 1 \\ Sekolah Tinggi Filsafat Theologi Jakarta, Indonesia \\ yonky.karman@stftjakarta.ac.id
}

\begin{abstract}
Abstrak: Penafsiran Kejadian 47:13-26 (terutama ay. 21) pada pokoknya dipengaruhi bacaan Septuaginta. Kendati potret positif Yusuf, ia juga terlihat sebagai kaki tangan Firaun untuk memperbudak rakyat Mesir. Kaitan dengan aktivitas perbudakan ini bertentangan dengan gambaran tradisional Yusuf sebagai sosok pemelihara hidup orang banyak. Solusi untuk potret negatif Yusuf biasanya merujuk bacaan Teks Masorah (MT) meski itu bukan rujukan bagi banyak terjemahan Alkitab modern dan tafsiran-tafisran. Septuaginta sebagai rujukan dalam kasus ini memang sulit ditolak meski bukan berarti Yusuf mempromosikan perbudakan rakyat Mesir di seluruh negeri, melainkan tepatnya sebuah bentuk kuno kapitalisme. Untuk itu, artikel ini memanfaatkan kritik naskah, studi kata, kritik bentuk, dan latar belakang agraria di Timur Tengah kuno. Kontribusi penelitian ini adalah untuk menunjukkan bahwa, alih-alih memperbudak, Yusuf merumuskan kebijakan politik pangan Mesir dalam konteks yang lebih luas dari realitas narasi Yusuf sebagai pemelihara hidup orang banyak.
\end{abstract}

Kata-kata kunci: perbudakan; Yusuf; politik pangan; pemelihara hidup; Mesir; bala kelaparan; bagi hasil

\section{PENDAHULUAN}

Kitab Kejadian menggambarkan Yusuf sebagai sosok berintegritas (39:1-20), "cerdas dan bijaksana" tiada tandingnya (41:39 BIMK). Di usia relatif muda 30 tahun (41:46), ia menjadi penguasa Mesir, negeri adidaya di Timur Tengah pada waktu itu. Jabatannya semacam perdana menteri (42:6 "mangkubumi"; MT שִּליט; NJPS 1 "vizier"; bdk. Pkh. 7:19 "penguasa"), orang nomor dua setelah firaun (41:40 "kuasa atas istanaku ... hanya takhta inilah kelebihanku daripadamu”),

\footnotetext{
${ }^{1}$ NJPS mengacu kepada terjemahan Perjanjian Lama dari Jewish Publication Society tahun 1985, yang juga dikenal sebagai JPS Tanakh.

${ }^{2}$ Kecuali lain disebut, kutipan ayat diambil dari LAI Terjemahan Baru (TB, 1974).
}

"bapak bagi firaun ... tuan atas seluruh istananya ... kuasa atas seluruh tanah Mesir" $(45: 8){ }^{2}$

Potret positif Yusuf menjadi ambigu dengan adanya narasi yang menggambarkan monopoli makanan dan perbudakan oleh kerajaan (47:13-26). Ia dipandang bertanggung jawab untuk praktik yang bertentangan dengan paradigma kapitalisme (Barat) dan demokrasi modern, seperti beberapa tafsiran berikut. Van Seters menyatakan bahwa perikop ini adalah kisah rakyat Mesir yang diperbudak oleh Yusuf. ${ }^{3}$ Dalam tafsirannya Coats

\footnotetext{
${ }^{3}$ John Van Seters, Prologue to History: The Yahwist as Historian in Genesis (Louisville: Westminster John Knox, 1992), 318.
} 
menyimpulkan bahwa perikop tersebut tidak memperlihatkan Yusuf sebagai administrator yang bijaksana melainkan menjelaskan akar penyebab dari sistem pajak abadi yang ia terapkan. ${ }^{4}$ Fretheim menilai bahwa tindakan keras yang Yusuf lakukan memang diperlukan dalam keadaan darurat, namun ia tetap menyalahkan Yusuf karena tidak memiliki visi yang cukup, terutama karena membuat tindakan daruratnya menjadi "suatu ketetapan ... sampai sekarang" (47:26). ${ }^{5}$ Sementara itu, Brueggemann berargumen bahwa kelihaian Yusuf juga membawa serta bahaya di dalamnya, yaitu eksploitasi, penindasan, dan perbudakan. ${ }^{6}$

Meski membaca narasi ini dari perspektif kesetiaan Tuhan dalam Kitab Kejadian, Kilnam Cha juga membaca Yusuf bukan sebagai sosok untuk diteladani karena adanya ambiguitas ini. Menurutnya, Allah memang menggunakan Yusuf untuk membebaskan rakyat dari kelaparan, namun hal itu tidak berarti bahwa Allah menyetujui kebijakan ekonominya yang kejam yang mengakibatkan orang Mesir menjadi budak Firaun. ${ }^{7}$ Berdasarkan perbandingan dengan teks-teks Perjanjian Lama terkait perbudakan, David Fuller dalam tesisnya membela model perbudakan Yusuf sebagai berbeda dari lainnya karena kedermawanannya, tetapi dengan begitu juga membenarkan pandangan bahwa Yusuf memperbudak rakyat Mesir. Masalahnya, gambaran Yusuf memperbudak rakyat Mesir bertentangan dengan gambaran dominannya sebagai pemelihara hidup orang banyak. Artikel ini hendak menjernihkan gambaran Yusuf dengan membaca ulang teks terkait secara saksama.

\footnotetext{
${ }^{4}$ George W. Coats, Genesis: With an Introduction to Narrative Literature (Grand Rapids: Eerdmans, 1983), 299.

${ }^{5}$ Terence E. Fretheim, "Genesis," dalam The New Interpreter's Bible, vol. 1 (Nashville: Abingdon, 1994), 654.

${ }^{6}$ Walter Brueggemann, Genesis (Atlanta: John Knox, 1982), 356
}

\section{METODE PENELITIAN}

Untuk itu, pertama-tama diperlihatkan jalan terjal Yusuf menuju kuasa dalam upaya membangun ketahanan pangan negeri Mesir, sesuai dengan gambaran Kitab Kejadian tentang Yusuf sebagai pemelihara hidup orang banyak. Untuk mengonstruksi realitas tekstual yang dipersoalkan, penulis memanfaatkan perbedaan tekstual (kritik naskah) sebagai petunjuk untuk membaca ulang naskah yang dipakai sebagai rujukan (textus receptus), medan makna kata/frasa (studi kata) serta bentuk ujaran Ibrani (kritik bentuk). Selain itu, pengetahuan agraria di Timur Tengah kuno juga penting sebagai untuk merekonstruksi realitas teks.

\section{HASIL DAN PEMBAHASAN}

\section{Jalan Menuju Kuasa}

Narasi kita dalam konteks migrasi Yakub sekeluarga dari Kanaan ke Mesir. Yusuf sudah lebih dulu di Mesir karena dijual sebagai budak dan akhirnya menjadi budak seorang pejabat Mesir. Karena berkelakuan sangat baik, Yusuf menjadi kepercayaan majikan, tetapi itu tak berlangsung lama sebab ia difitnah oleh nyonya majikan. Kurva kehidupan Yusuf jatuh lebih dalam, dibui seperti orang jahat, tetapi ia tetap berkelakuan baik sehingga kepala penjara "mempercayakan semua tahanan dalam penjara itu kepada Yusuf" (39:22). Tempat Yusuf ditahan pun terpisah, "di rumah kepala pengawal raja" (40:3).

Dua pejabat istana, kepala juru minum dan kepala juru roti, kena kasus hukum dan ditahan di rumah kepala pengawal raja, di

\footnotetext{
${ }^{7}$ Kilnam Cha, "Joseph's Unjust Economic Policies in Genesis 47:13-26," Leaven 24 (2016): 190-193.

${ }^{8}$ Untuk survei komprehensif lireratur terkait pro dan kontra citra positif Yusuf, lihat David J. Fuller, An Examination of Joseph's Enslavement of the Egyptians in Gen 47:13-26 in light of Relevant Slavery Texts across the Tanakh (tesis; McMaster Divinity College, 2013), 9-22.
} 
bawah pengawasan Yusuf. Suatu malam, keduanya bermimpi tetapi tak tahu maknanya. Ketika Yusuf datang melayani keperluan mereka, terjadilah pembicaraan seputar mimpi mereka. Untuk mimpi kepala juru minum, Yusuf menjelaskan bahwa yang bersangkutan dalam tiga hari akan kembali ke posisi semula, tak lupa ia berpesan agar jangan lupa menolong dia bebas dari penjara. Melihat tafsir baik mimpi rekannya, kepala juru roti juga juga mau menerima tafsir mimpi, tetapi Yusuf berkata bahwa ia akan dieksekusi dalam tiga hari. Pada hari ketiga, kedua tahanan itu dipanggil menghadap raja. Benarlah tafsir mimpi dari Yusuf: yang satu kembali ke posisi semula, satunya lagi dieksekusi.

Dua tahun setelah kepala juru minum kembali bekerja, Firaun bermimpi sedang berdiri di tepi Sungai Nil (41:1). Dalam mimpi Firaun, muncul 7 ekor sapi gemuk dari dalam sungai dan makan rumput di tepi sungai; lalu muncul 7 ekor sapi kurus kering yang memakan 7 ekor sapi gemuk itu. Juga tampak 7 bulir gandum gemuk berisi pada satu tangkai, lalu tampak juga 7 tangkai bulir gandum kurus yang menelan 7 bulir gandum gemuk itu. Ketika terjaga, ia gelisah dengan mimpinya yang aneh itu. "Semua ahli dan semua orang berilmu di Mesir" dipanggil ke istana untuk mengartikan mimpi itu "tetapi seorang pun tidak ada yang dapat mengartikannya kepadanya" (41:8).

Di zaman kuno, mimpi memiliki kaitan langsung dengan kepercayaan agama, apalagi mimpi orang penting seperti raja, orang yang paling bertanggung jawab atas kesejahteraan seluruh rakyat Mesir. ${ }^{9}$ Ada mimpi sederhana dan langsung jelas, ada mimpi simbolis yang harus dimaknai. Pertama-tama mimpi harus diceritakan ulang, barulah kemudian ditafsir. Salah satu profesi penting waktu itu adalah juru tafsir mimpi merangkap peramal. Profesi peramal bisa membawa orang sampai ke istana dan Mesir dikenal antara lain karena para peramalnya yang notabene orang berpengetahuan. Peramal dari kalangan agama (imam) disebut (41:8 "ahli"; Dan. 1:20 BIMK "peramal") ${ }^{10}$ dan yang dari kalangan orang bijak disebut דָָָָם (41:8 "orang berilmu"). Dengan berhasil mengumpulkan para peramal, istana menjadi representasi pusat pengetahuan. Knowledge is power. Pengetahuan adalah jalan menuju kuasa. Diperhadapkan dengan mimpi aneh itu, ternyata ilmuwan istana tak berdaya, pertanda melemahnya otoritas istana sebagai pusat pengetahuan.

Dalam ketakberdayaan istana, kepala juru minum teringat Yusuf dan merekomendasikan nama itu kepada Firaun. Yusuf berkata kepada penguasa Mesir itu bahwa Allah melalui mimpinya itu "telah memberitahukan ... apa yang hendak dilakukan-Nya" (41:25). Tujuh ekor sapi gemuk dan tujuh bulir gandum gemuk berarti "tujuh tahun kelimpahan" di seluruh Mesir dalam waktu dekat (41:29; ay. 35 "tahun-tahun baik"). Tujuh ekor sapi kurus dan tujuh bulir gandum kurus berarti "tujuh tahun kelaparan" setelah masa kelimpahan $(41: 27,30,36,54)$. Secara keseluruhan, penyebutan "tujuh tahun kelaparan" dua kali lebih banyak, memperlihatkan fokusnya adalah pada krisis pangan dan urgensi kebijakan pangan yang tepat sebagai solusi krisis.

Solusi krisis yang ditawarkan Yusuf adalah segera angkat seorang yang "cerdas dan

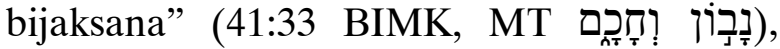
untuk mengatur negeri dan membawahi "penilik-penilik" (41:34). Para penilik mendorong dan memastikan peningkatan produksi ladang-ladang selama tujuh tahun kelimpahan. Kerajaan membeli seperlima panen 
gandum untuk memperkuat stok pangan nasional guna mengantisipasi paceklik panjang. Di masa normal, kebijakan seperti itu bertentangan dengan kondisi alam Mesir yang dikenal subur.

Mimpi Firaun pertanda birokrasi istana gagal antisipasi krisis. Mimpi dari dunia atas menerobos istana, peringatan dari Sang Penguasa untuk penguasa duniawi. Kini, tafsir mimpi sudah diberikan (apakah dipercaya?), juga solusi krisis (apakah diikuti?). Apakah Firaun lebih percaya rencana yang disusun birokratnya pada waktu normal atau menerima usulan tak lazim dari orang biasa di luar birokrasi? Firaun sudah belajar dari kegagalan birokrasi istana menafsir mimpinya, gagal mengantisipasi krisis, dan kini ia lebih memercayai usulan tak lazim dari luar birokrasi. Ia menganggap tiada sosok yang lebih tepat selain Yusuf sebagai solusi krisis.

Pada masa tujuh tahun kelimpahan, Yusuf membangun kota-kota lumbung di Mesir (41:35-36, 48), mengelilingi negeri untuk memastikan pengumpulan seperlima hasil panen dari desa-desa untuk disimpan di kota lumbung terdekat. Sentra stok pangan yang tersebar di seluruh negeri memperpendek jalur distribusi pangan; orang lapar akan lebih dulu mati jika tak segera mendapat bantuan makanan. Demikian Mesir selamat dari bencana dahsyat bala kelaparan, bahkan mampu menolong penduduk tempat lain seperti Kanaan. Bukan orang dalam yang menyelesaikan krisis Mesir, melainkan orang luar yang tadinya sama sekali tak diperhitungkan, tahanan di penjara, yang kemudian berkuasa dan mengambil kebijakan-kebijakan tepat meski tak lazim.

\footnotetext{
${ }^{11}$ Claus Westermann, Genesis 37-50 (Minneapolis: Augsburg, 1986), 174.

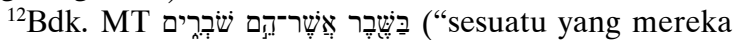
remukkan") yaitu biji gandum hasil penebahan, dengan

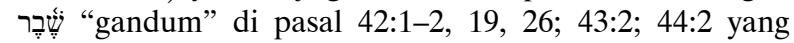
diberikan Yusuf kepada keluarganya. Lihat Victor P. Hamilton, The Book of Genesis: Chapter 18-50 (Grand Rapids: Eerdmans, 1995), 618n39.
}

\section{Membangun Ketahanan Pangan}

Latar waktu narasi kita adalah suatu ketika dari masa tujuh tahun kelaparan, ketika rakyat "berteriak meminta roti kepada Firaun" dan mereka disuruh pergi "kepada Yusuf" untuk membeli gandum (41:55). ${ }^{11}$ Dengan istana menguasai stok gandum nasional, semua uang hasil penjualan gandum masuk kas kerajaan (47:14). ${ }^{12}$ Setelah makanan dan uang rakyat habis, mereka datang kembali kepada Yusuf dan berkata, "Berilah makanan kepada kami! Mengapa kami harus mati di depanmu sebab tidak ada lagi uang?" (47:15). Yusuf menawarkan pembelian makanan dengan sistem barter: "Jika tidak ada lagi uang, berilah ternakmu ... aku akan memberi makanan ${ }^{13}$ kepadamu sebagai ganti ternakmu itu" (ay. 16). Harta bergerak paling berharga dalam masyarakat agraris adalah ternak (kuda, kambing domba, lembu sapi, keledai) yang bisa berfungsi antara lain untuk sarana transportasi, membawa beban, bertani, bahan makanan (dagingnya, susunya), bahan pakaian (kulitnya). Karena mustahil menampung semua ternak rakyat, hewanhewan itu de facto masih dipakai rakyat tetapi de jure milik Firaun. ${ }^{14}$

Bala kelaparan berlangsung lama sehingga persediaan makanan hasil barter hanya bertahan setahun. Hal ini diperlihatkan dalam pasal 47:18-19 berikut ini

Setelah lewat tahun itu, datanglah mereka kepadanya, pada tahun yang kedua, ${ }^{15}$... "Uang kami habis ... ternak kami menjadi milik tuanku, tidaklah ada lagi yang tinggal yang dapat kami serahkan kepada tuanku

\footnotetext{
${ }^{13}$ Ketiadaan objek langsung (ִִֶֹ ("makanan”) pada teks Ibraninya bisa dibandingkan dengan klausa lengkap pada ayat berikutnya dengan konstruksi gramatikal sama tetapi bukan klausa elipsis (demikian teks LXX, Pentateukh Samaria, Targum Yonatan). Lihat Hamilton, The Book of Genesis, 614.

${ }^{14}$ Westermann, Genesis, 174.

${ }^{15}$ Meski TB "pada tahun yang kedua" bisa menjadi

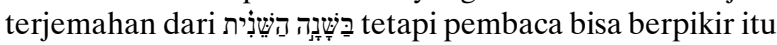


selain badan kami dan tanah kami. Mengapa kami harus mati di depan matamu? ... belilah kami dan tanah kami sebagai ganti makanan ... kami dengan tanah kami akan menjadi hamba kepada firaun; berikanlah benih, ${ }^{16}$ supaya kami hidup ... dan supaya tanah itu jangan menjadi tandus."

Makanan masih menjadi isu hidup dan mati, tetapi yang bakal mati kini bertambah: tanah yang tadinya subur akan jadi tandus, terbengkalai tak ditanami, karena yang mengurusnya mati kelaparan. Rakyat pun siap berbuat apa saja untuk bertahan hidup, dengan dua syarat. Pertama, istana menjamin ketersediaan benih tanaman demi kelangsungan pertanian rakyat. Kedua, mereka dipekerjakan di tanah yang tadinya milik mereka. Berbeda dari skema barter pertama, barter kedua berasal dari inisiatif rakyat, tanah dan tenaga mereka ditukar dengan makanan dan benih. Dengan menjual tanah kepada Firaun berarti mereka bukan lagi petani mandiri, menjadi hamba Firaun.

Yusuf setuju dengan skema barter yang diinisiasi oleh rakyat, ${ }^{17}$ seperti yang terlihat di ayat $20,23-24$ berikut ini

Yusuf membeli segala tanah orang Mesir ... negeri itu menjadi milik Firaun ... Berkatalah Yusuf kepada rakyat itu, "Pada hari ini aku telah membeli kamu dan tanahmu untuk firaun; inilah benih bagimu supaya kamu dapat menabur di tanah itu. Mengenai hasilnya, kamu harus berikan

adalah tahun kedua dari tujuh tahun kelaparan, sementara maksudnya hanya tahun sesudah barter pertama (BIMK "pada tahun berikutnya"; NKJV, NJB, NASB "the next year"; NRSV, NIV "the following year") yaitu tahun menabur dan menuai (bdk. 47:23-24). Lihat Gerhard von Rad, Genesis (Philadelphia: Westminster, 1972), 410.

${ }^{16}$ Tambahan LXX iv $\alpha \sigma \pi \varepsilon i ́ \rho \mu \varepsilon v$ ("supaya kami bisa menabur").

${ }^{17}$ Nahum M. Sarna, Genesis (Philadelphia: Jewish Publication Society, 1989), 323, "a moral judgment on this situation is subtly introduced into the narrative by shifting the onus of responsibility for the fate of the peasants from Joseph to the Egyptians themselves." seperlima bagian kepada firaun dan yang empat bagian ... menjadi benih untuk ladangmu ... makanan kamu dan ... yang ada di rumahmu"

Yusuf membeli semua tanah rakyat yang kini beralih menjadi tanah kerajaan (milik Firaun), tetapi makanan untuk penghidupan mereka dijamin oleh pemerintah, juga ketersediaan benih untuk produksi, dalam suatu skema bagi hasil (bdk. 41:34-36). Apabila panen berhasil, mereka menikmati empat perlima dari hasil dengan satu perlima untuk Firaun. Rakyat hanya memakai pengetahuan dan keterampilan kerja mereka, bermodal waktu dan tenaga; kalau panen gagal, kerugian materiel ditanggung pemerintah. ${ }^{18} \mathrm{Ini}$ bukan pemajakan dalam arti modern, sebab di sini negara menjamin penghidupan rakyat dan modal kerja mereka untuk bertani. ${ }^{19}$

Sepintas bagian untuk Firaun cukup besar, tetapi tidak juga jika dilihat dari praktik dunia kuno (bdk. 1 Makabe 10:30 "sepertiga"). ${ }^{20}$ Semasa Hammurabi, bagian panen untuk raja dari tanah kerajaan berkisar antara dua pertiga hingga setengah dari hasil panen setelah dipotong biaya produksi. Tingkat riba untuk pinjaman dalam bentuk gandum biasanya 33 persen dan untuk perak 20 persen (tak jelas apakah dibayar per tahun atau per bulan). ${ }^{21}$ Demikian rakyat Mesir bertani di tanah negara (bukan petani mandiri), sebagai penggarap, dengan sistem bagi hasil. Biasanya, bagian penggarap lebih sedikit daripada pemilik tanah, tetapi di sini bagian penggarap empat kali lebih besar daripada pemilik

\footnotetext{
${ }^{18}$ Tanah para imam (lahan kuil) dikecualikan dari sistem bagi hasil ini sebab mereka "mendapat tunjangan tetap dari firaun" $(47: 22,26)$. Dengan menikahi "Asnat, anak Potifera, imam di On” (41:45, 50; 46:20), Yusuf sangat dekat dengan kelompok para imam di Mesir.

${ }^{19} \mathrm{Bdk}$. Daniel C. Snell, Life in the Ancient Near East: 3100-332 BCE (New Haven: Yale University Press, 1997), 21, "a tax in labor on otherwise free peasants."

${ }^{20} \mathrm{Bdk}$. von Rad, Genesis, 411; Westermann, Genesis, 174.

${ }^{21}$ Snell, Life in the Ancient Near East, 58.
} 
tanah. Budak mustahil menerima bagian sebesar itu. Dalam status sebagai milik majikan, bahkan budak bekerja tanpa upah (sistem bagi hasil tak berlaku) dan seluruh hasil panen adalah milik majikan. Budak hanya menerima ransum secukupnya untuk bertahan hidup dan bekerja.

Jauh sebelum ini, Walter Lempp menyebut praktik agraria Yusuf ini sebagai "kapitalisme negara," 22 yang dibayangkan sudah berlangsung lama di Mesir hingga zaman penulis atau narator (ay. 26 "sampai sekarang"), ketika orang sudah tak tahu lagi asal-usulnya, ${ }^{23}$ meski tampaknya itu kekeliruan etiologis. ${ }^{24}$ Keterangan etiologis memang biasanya ada pada bagian akhir narasi, menjelaskan asalusul sesuatu (nama atau keadaan) yang tak diketahui lagi oleh pembaca narasi dan perlu dijelaskan (bdk. ay. 22 "itulah sebabnya mereka tidak menjual tanahnya"). Narasi ini mungkin etiologi dalam bentuk midrash yang diilhami pasal 41:53-57, ${ }^{25}$ yang memperlihatkan keheranan orang Israel atas sistem agraria di tanah Mesir (tanah milik raja atau penguasa dengan rakyat sebagai penggarap tanah). Sistem agraria di Mesir ini berbeda dari sistem agraria menurut hukum Taurat yang mengakui kepemilikan tanah secara individual. ${ }^{26}$ Sebagai contoh, Ahab yang dengan cara licik dan keji merebut kebun anggur Nabot (1Raj. 21), di dalam penghakiman nabi Elia, telah melakukan apa yang jahat di mata Tuhan. Menurut hukum Taurat, orang yang sudah menggadaikan tanahnya atau menjual diri sebagai budak, bisa ditebus. Jika tidak

\footnotetext{
${ }^{22}$ Walter Lempp, Kejadian 37:1-50:26 (Jakarta: BPK Gunung Mulia, 1977), 130.

${ }^{23}$ Pembangunan kota lumbung berlanjut di Mesir (Kel. 1:11), salah satu megaproyek Salomo (1Raj. 9:19; 2Taw. 8:4, 6).

${ }^{24}$ Lihat von Rad, Genesis, 411.

${ }^{25}$ John Van Seters, Prologue to History: The Yahwist as Historian in Genesis (Louisville: Westminster John Knox, 1992), 318.

${ }^{26}$ Roland de Vaux, Ancient Israel: Its Life and Institutions (Grand Rapids: Eerdmans, 1997), 140, 164;
}

ditebus, tanah atau orang itu otomatis bebas pada tahun Yobel (Im. 25:28, 54).

\section{RAKYAT MESIR DIPERBUDAK?}

Beberapa terjemahan Alkitab menggambarkan Yusuf memperbudak rakyat Mesir. Terjemahan TB berbunyi, "Dan tentang rakyat itu, diperhambakannyalah mereka di daerah Mesir dari ujung yang satu sampai ujung yang lain" (47:21). Rujukan yang dipakai TB dan beberapa versi Alkitab lain yang menyebut Yusuf memperbudak rakyat Mesir adalah terje-

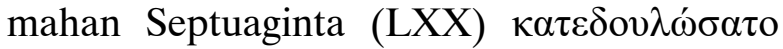
yang artinya memperhamba atau memperbudak (Vorlage LXX העּעִביד). ${ }^{27}$ Memang teks LXX itu didukung Pentateukh Samaria ${ }^{28}$ dan perujukan itu direkomendasikan leksikon Ibrani. ${ }^{29}$ Meski teks tak eksplisit siapa subjek kata kerja itu, tak sulit untuk membacanya sebagai Yusuf (NIV "Joseph reduced the people to servitude"). Namun, untuk menyelamatkan citra Yusuf dari aktivitas perbudakan dan memanfaatkan subjek yang tak eksplisit itu, ada beberapa terjemahan yang menjadikan Firaun sebagai subjek (NEB "Pharaoh set them to work as slaves"). ${ }^{30}$ Model terjemahan lain yang tampaknya bertujuan sama adalah mengubah terjemahannya jadi dalam bentuk kalimat pasif; rakyat Mesir diperbudak tanpa disebutkan siapa pelakunya (NAB "the people were reduced to slavery").

Upaya menyelamatkan citra Yusuf dari aktivitas perbudakan yang paling berterima adalah mengadopsi bacaan MT העּעִביר (secara harfiah berarti memindahkan). Hal ini bisa

Gordon J. Wenham, Genesis 16-50 (Waco: Word, 1994), 448.

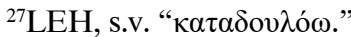

${ }^{28}$ Wenham, Genesis, 437n21; Hamilton, The Book of Genesis, 616n23.

${ }^{29} \mathrm{BDB}, 713,719$.

${ }^{30}$ Dalam Homilies on Genesis 16:1, Origen menganggap Firaun memperbudak rakyatnya dan mereka rela menjadi budak ("voluntary bondage"), lihat Mark Sheridan, ed., Genesis 12-50, Ancient Christian commentary on Scripture: Old Testament, vol. 2 (Downers Grove: InterVarsity, 2002), 310. 
dilihat pada Tabel 1 yang membandingkan beberapa terjemahan, yaitu LAI Terjemahan
Lama (TL), versi Alkitab Inggris (N/KJV), dan kitab suci Yahudi (JPS, NJPS). ${ }^{31}$

Tabel 1. Perbandingan Terjemahan Kejadian 47:21

\begin{tabular}{|c|c|}
\hline Versi & Teks \\
\hline MT & 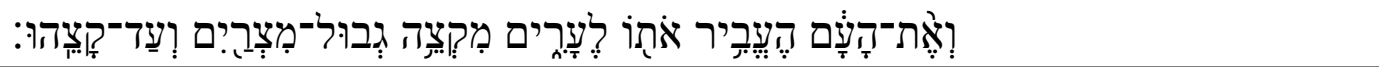 \\
\hline LAI TL & $\begin{array}{l}\text { setelah itu dipindahkannjalah orang banjak itu daripada sebuah negeri kepada } \\
\text { sebuah negeri, daripada suatu udjung perhinggaan tanah Mesir sampai kepada } \\
\text { udjung jang lain }\end{array}$ \\
\hline KJV & $\begin{array}{l}\text { and as for the people, he removed them to cities from one end of the borders of } \\
\text { Egypt even to the other end thereof }\end{array}$ \\
\hline NKJV & $\begin{array}{l}\text { and as for the people, he moved them into the cities, from one end of the borders of } \\
\text { Egypt to the other end }\end{array}$ \\
\hline JPS & $\begin{array}{l}\text { and as for the people, he removed them city by city, from one end of the border of } \\
\text { Egypt even to the other end thereof }\end{array}$ \\
\hline NJPS & $\begin{array}{l}\text { and he removed the population town by town, from one end of Egypt's border to the } \\
\text { other }\end{array}$ \\
\hline
\end{tabular}

Penafsir yang merujuk pembacaan MT berusaha menjelaskan maknanya meski pada akhirnya spekulatif. Nahum Sarna, penafsir Yahudi yang menjadikan MT sebagai basis teksnya, menjelaskannya sebagai penggusuran rakyat dari tanah yang kini sudah jadi milik negara. ${ }^{32}$ Sarna merujuk kasus pembuangan orang Israel, ${ }^{33}$ tetapi sesungguhnya pembuangan itu bukan pemindahan seisi penduduk (bedol) kota. Calvin membaca tujuan migrasi massal itu agar rakyat Mesir menjadi petani mandiri atau menerima makanan. ${ }^{34}$ Keil dan Delitzsch menjelaskan migrasi itu demi akses ke kota-kota lumbung. ${ }^{35}$ Ronald Youngblood menjelaskan migrasi massal itu hanya selama rakyat menerima pembagian makanan. ${ }^{36}$

${ }^{31}$ Versi JPS mengacu kepada terjemahan Jewish Publication Society tahun 1917.

${ }^{32}$ Sarna, Genesis, 322, "a population transfer, probably to oust farmers from nationalized lands."

${ }^{33}$ Sarna, Genesis, 371.

${ }^{34}$ John Calvin, Commentaries on the First Book of Moses Called Genesis, vol. 2, terj. John King (Grand Rapids: Eerdmans, 1948), 411-412, "Joseph removes the people to places where they could become free cultivators or the people move to cities in order to receive provisions."

35 C.F. Keil and F. Delitzsch, The Pentateuch, Commentary on the Old Testament, vol. 1 (1885; repr., Peabody: Hendrickson, 2001), 243-244, “Joseph ... distributed the population of the whole land according to the cities in which the corn was housed, placing them partly in the
Sementara itu, ada pula penafsir-penafsir yang meragukan pembacaan MT. Casey Strine melihat migrasi leluhur Israel karena kelaparan sebagai sebuah tema dalam Kitab Kejadian, tetapi migrasi massal rakyat Mesir tak disinggungnya. ${ }^{37}$ Dan, memang sulit membayangkan fenomena bedol kota terjadi di seluruh negeri Mesir. Speiser menyatakan keraguannya akan hal tersebut dengan berkata, "Nor would the transfer of the entire rural population-the overwhelming majority of the people-be practicable or serve any

cities themselves, and partly in the immediate neighbourhood."

${ }^{36}$ Ronald F. Youngblood, The Book of Genesis: An Introductory Commentary (Grand Rapids: Baker, 1991), 270, "the Egyptian people were ordered to move into the cities temporarily until the seed for planting could be efficiently distributed to them."

${ }^{37}$ Beberapa contoh migrasi leluhur Israel: Abraham bermigrasi untuk sementara ke Mesir (12:10), Ishak ke Gerar di tanah Filistin (26:1), Yakub ke Mesir setelah mengetahui Yusuf masih hidup (46:1-47:12). Casey A. Strine, "The Famine in the Land Was Severe: Environmentally Induced Involuntary Migration and the Joseph Narrative," Hebrew Studies 60 (2019): 55-69, https://doi.org/10.1353/hbr.2019.0020. 
conceivable purpose." 38 Di samping itu, Wenham juga menyatakan kesulitan pembacaan MT berikut ini:

The $M T$ reading ... is difficult to understand, because they needed to stay on their holdings and cultivate them ... even though the land was owned by the crown ... Nor would they have moved to the cities just to be near the granaries. ${ }^{39}$

Salah satu prinsip kritik naskah Perjanjian Lama adalah tidak apriori mengutamakan teks Ibrani hanya karena teksnya jelas. ${ }^{40}$ Dalam kritik naskah, apabila dua teks kuno sama-sama jelas dengan arti berbeda (seperti dalam kasus teks yang sedang dibicarakan), salah satu kriteria internal untuk memilih adalah yang paling sesuai dan sejalan dengan konteks. ${ }^{41}$ Bacaan LXX sejalan dengan alur cerita. ${ }^{42}$ Rakyat awalnya menjual tanah dan diri mereka kepada Firaun asalkan mereka mendapat makanan dan benih tanaman (ay. 19). Yusuf sepakat dengan proposal itu dan semua tanah rakyat dibeli (ay. 20, 23). Yusuf mempekerjakan mereka dengan sistem bagi hasil yang menarik: empat bagian dari hasil panen untuk mereka, satu bagian untuk Firaun (ay. 24). Rakyat sebagai hamba Firaun pun sangat berterima kasih, "Biarlah kami menjadi hamba kepada Firaun" (ay. 25), ${ }^{43}$ bentuk ujaran ekspresi tata krama rakyat menghamba kepada raja. ${ }^{44}$

Perbedaan antara bacaan LXX dan MT bisa dijelaskan dari sudut kerancuan dalam proses penyalinan teks (scribal error). Bentuk huruf 7

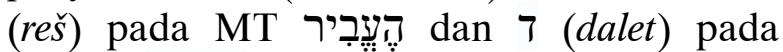
Vorlage העֵֶׁביד mirip sekali. ${ }^{45}$ Kasus kerancuan di antara kedua huruf itu sering ditemui antara MT dan Vorlage LXX. Perbedaan pembacaan ini bisa dilihat pada Tabel 2.

Tabel 2. Perbandingan Perbedaan Pembacaan karena Penggunaan $\urcorner($ reš $)$ dan 7 (dalet)

\begin{tabular}{|c|c|c|}
\hline Nas & Penggunaan $\urcorner($ reš $)$ & Penggunaan $\urcorner$ (dalet) \\
\hline Yer. 15:14 & 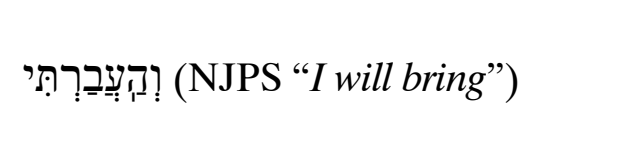 & 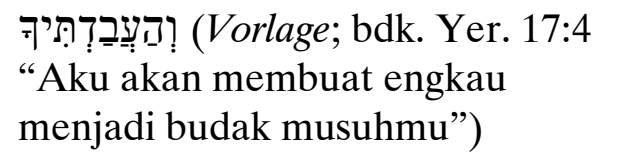 \\
\hline Yes. 23:10 & $\begin{array}{l}\text { עִבְרִ (NJPS “traverse”; BIMK } \\
\text { "pergilah”; NRSV “cross over”) }\end{array}$ & עִבְדִדי (Vorlage; "kerjakanlah”) \\
\hline Kej. 43:14 & אַח ("yang lain itu”) & אָָָד (Vorlage “yang satu itu”) \\
\hline 1Sam. 21:7/8 & הָאָרַרִּי (Vorlage "seorang Aram") & 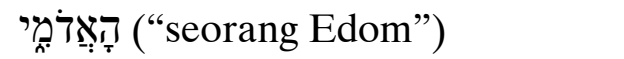 \\
\hline Yer. 2:20 & 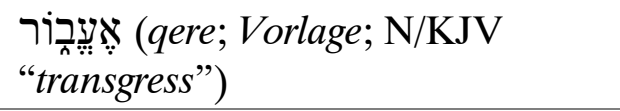 & 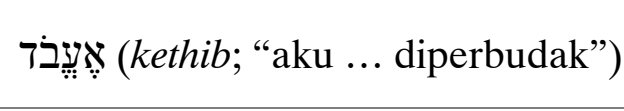 \\
\hline Kej. 10:4 & $\begin{array}{l}\text { רוֹדְנְנָים ("Rodanim"; Vorlage; LXX; } \\
\text { BIMK "Rodes"; bdk. 1Taw. 1:7) }\end{array}$ & ("Dodanim”) (“דְנִים ("Dod) \\
\hline
\end{tabular}

${ }^{38}$ E. A. Speiser, Genesis (New York: Doubleday, 1962), 353.

${ }^{39}$ Wenham, Genesis, 449.

${ }^{40}$ Ernst Würthwein, The Text of the Old Testament: An Introduction to the Biblia Hebraica (Grand Rapids: Eerdmans, 1995), 50, "For the early church [LXX] was simply the standard form of the Old Testament."

${ }^{41} \mathrm{P}$. Kyle McCarter, Textual Criticism: Recovering the Text of the Hebrew Bible (Philadelphia: Fortress, 1986), 74.

${ }^{42}$ Hamilton, The Book of Genesis, 616n23.
${ }^{43}$ Coats, Genesis, 299. "people's agreement."

${ }^{44}$ Westermann, Genesis, 176, "courtly language."

${ }^{45}$ McCarter, Textual Criticism, 45, "Because dalet and reš closely resembled each other in the scripts of most periods, mistakes of one for the other led to many divergences between various witnesses to the texts." 
Meski Vorlage הַעִברביד lebih konsisten dengan konteks, bagaimana dengan artinya "memperbudak"? Dalam Kejadian 29:15 kata ini berarti "bekerja." Namun bentuk hiphil עבד memang sering berarti kerja paksa (Kel. 1:13 "memaksa ... bekerja"; 6:5 "diperbudak"; 2Taw. 2:17-18 "dijadikannya kuli"). Verba קנה dalam Kejadian 47 (ay. 19, 23 “membeli”) memang dipakai dalam konteks pembelian budak (bdk. Kel. 12:44 "budak belian"). Karena itu, wajar pada pandangan pertama untuk memaknai Yusuf הְֶּבריד rakyat Mesir sebagai memperbudak.
Namun, teks memperlihatkan mereka bekerja sebagai penggarap, sebagai hamba Firaun (NJPS, NJB "serfs"), bukan budak. Dua kali

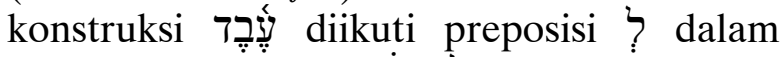

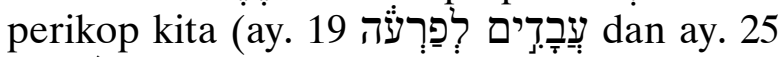
"menjadi hamba kepada Firaun") secara idiomatik tak mesti "menjadi budak," namun cukup dalam arti "menjadi hamba", menghamba kepada atau bekerja untuk melayani Firaun. Tabel 3 berikut ini memperlihatkan beberapa contoh konstruksi ungkapan Ibrani sejenis.

Tabel 3. Beberapa Contoh Konstruksi צֶּרֶ diikuti preposisi ?ִ

\begin{tabular}{|c|c|c|}
\hline Nas & Konstruksi MT & Terjemahan \\
\hline Ams.11:29 & 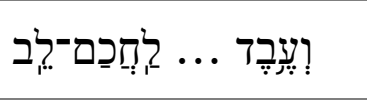 & $\begin{array}{l}\text { "Orang bodoh akan melayani orang yang bijaksana" } \\
\text { (BIMK) }\end{array}$ \\
\hline Ams. 22:7 & 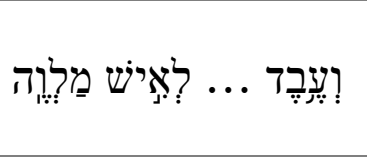 & $\begin{array}{l}\text { "Orang yang meminjam dikuasai oleh orang yang } \\
\text { meminjamkan" (BIMK). "The borrower is servant to the } \\
\text { leader" (JPS, NKJV, NIV). }\end{array}$ \\
\hline Ams. 12:9 & 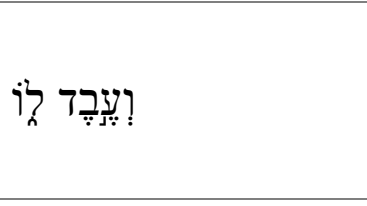 & $\begin{array}{l}\text { "Lebih baik menjadi orang kecil tetapi bekerja untuk diri } \\
\text { sendiri" (TB). "Better a lowly man who supports himself" } \\
\text { (NAB). "It is better to be an ordinary person working for a } \\
\text { living" (TEV). }\end{array}$ \\
\hline
\end{tabular}

Jadi, dari contoh penggunaan di atas, dapat dikatakan rakyat Mesir bekerja atau dipekerjakan untuk Firaun (bdk. Yeh. 29:18 הֶעְבריד, "menyuruh ... bekerja").

Respons sangat positif rakyat Mesir untuk kebijakan agraria Yusuf juga perlu dipertimbangkan. ${ }^{46}$ Mereka berkata kepada Yusuf, “... kiranya kami mendapat kasih tuanku

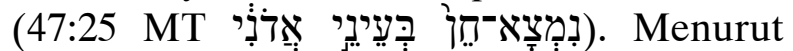
bentuk ujaran, itu adalah ungkapan terima kasih (NJPS, NAB "we are grateful to my lord"; BIMK "kami berterima kasih"). Yusuf tidak memperlakukan mereka sebagai budak yang hak-hak asasinya dilanggar, seperti nanti pengalaman bani Israel sebagai budak di Mesir (Kel. 2:23-24 "mengeluh ... berseruseru ... minta tolong ... mengerang"). Di mata rakyat Mesir, Yusuf telah "memelihara hidup" (חיה, konstruksi hiphil) mereka dari mati kelaparan. Verba Ibrani ini juga dipakai Yusuf ketika bersaksi di hadapan saudarasaudaranya yang sudah siap menjadi budaknya (bdk. 44:9, 16; 50:18), untuk menegaskan bahwa sudah jalan hidupnya untuk memelihara (bukan memperbudak) hidup banyak orang, termasuk keluarga besarnya (45:11; 47:12; 50:21; MT כִלְכַּל "memelihara"). Saat menyingkapkan identitas dirinya kepada saudara-saudaranya, Yusuf berkata, "Allah telah menyuruh aku mendahului kamu ... untuk memelihara hidupmu (45:7). Ketika Yakub sudah meninggal dan saudara-saudaranya menjadi takut kepada Yusuf, ia berkata, "Kamu telah mereka-rekakan yang jahat terhadap aku, tetapi Allah telah mereka-

\footnotetext{
${ }^{46}$ Lihat von Rad, Genesis, 410, "the nation is grateful"; Wenham, Genesis, 447, "the grateful Egyptians"; Westermann, Genesis, 176, "expression to their gratitude."
} 
rekakannya untuk kebaikan, dengan maksud ... memelihara hidup suatu bangsa yang besar

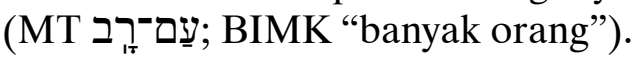

Secara logika, mustahil Yusuf yang notabene orang asing (juga bukan bagian dari elite penguasa seperti Hyksos) mendiskriminasi rakyat Mesir (mayoritas penduduk), sementara keluarganya yang bermukim di Gosyen (di Delta Nil) tak diperbudak. Juga sulit dibayangkan bagaimana Firaun memperbudak rakyat sendiri (pelaku penjajahan biasanya bangsa asing), bahkan seluruh rakyat. Karena itu, meski memilih bacaan LXX, Victor Hamilton menyimpulkan, "Joseph is not a callous, unethical taskmaster ... is a nondiscriminating savior." ${ }^{47}$ Narasi ini konsisten dengan sosok Yusuf yang dibangun Kitab Kejadian: Yusuf adalah pemelihara hidup orang banyak.

Dalam sistem agraria di dunia Timur Tengah Kuno, para raja bak tuan tanah negeri. Tanah bisa langsung dikelola istana atau disewakan, bisa juga dipinjamkan kepada para abdi raja untuk digarap dan dipetik hasilnya sebagai ganti gaji mereka (Ing. fief; bdk. tanah bengkok). Ada catatan-catatan dari semua periode di Mesopotamia tentang tanah di seluruh negeri sebagai kepunyaan raja dan praktik sejenis tanah bengkok. ${ }^{48}$ Karena raja Mesir adalah titisan dewa, secara teoritis pemilik segala sesuatu di wilayah kerajaannya (penguasa absolut), tetapi dalam praktiknya rakyat juga bisa memiliki tanah pribadi dalam semua periode kuno. Hanya kuil-kuil di Mesir dikecualikan. ${ }^{49}$ Pada periode Antara Kedua $( \pm$ 1803-1550 SM, dinasti ke-13 sampai ke-15),

\footnotetext{
${ }^{47}$ Hamilton, The Book of Genesis, 618.

${ }^{48}$ Lihat de Vaux, Ancient Israel, 124.

${ }^{49}$ Westermann, Genesis, 174, "Only from a distance could the life of the Egyptian farmers as a whole appear as bondage ... in all periods there was free landed property."

50 Kata Yunani yang bagi orang Mesir berarti "penguasa-penguasa dari negeri-negeri asing", berbahasa Semit, memiliki teknologi dan keterampilan militer tinggi, sebutan untuk para penyerbu dari Asia (Aram-Palestina). Biasanya periode Hyksos menjadi latar narasi Yusuf di Mesir.
}

penguasa Mesir adalah Dinasti Hyksos, ${ }^{50}$ dibedakan dari Firaun sebagai penguasa pribumi. ${ }^{51}$ Hak rakyat memiliki tanah sendiri tampaknya dilegalisasi pada periode Kerajaan Tengah ( \pm 2055-1650 SM, dinasti ke-11 sampai ke-13). Sesudah orang Hyksos diusir, mulailah periode Kerajaan Baru $( \pm 1540$ 1070 SM, dinasti ke-18 sampai ke-20), Firaun Ra'amses II (1303-1213 SM) adalah salah satunya. Mungkin selanjutnya dipandang perlu kehadiran dinasti yang kuat, sehingga para firaun mengklaim hak mereka atas seluruh tanah Mesir dengan mengurangi hak-hak rakyat. Meski sedikit sekali pengetahuan kita tentang sistem agraria kuno Mesir dan tak mudah menempatkan kisah Yusuf dalam salah satu periode sejarah Mesir, sejauh ini belum ada catatan sejarah bahwa rakyat Mesir dulu kala pernah bergolak karena perbudakan nasional oleh raja sendiri. Tentu ketiadaan data sejarah (argument from silence) tak lalu berarti Yusuf tak memperbudak, tetapi juga tak perlu terlalu cepat membaca sebaliknya. ${ }^{52}$

Sebenarnya, TB "diperhambakannyalah" (satu-satunya dalam TB) tak sama dengan "diperbudak." ${ }^{53}$ Memperhamba adalah tindakan membuat seseorang menghamba (mengabdi), tak mesti memperbudak. Tampaknya penerjemah Lembaga Alkitab Indonesia dulu dengan sadar memilih kata ini untuk LXX

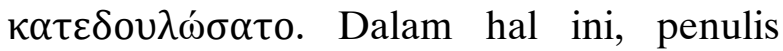
menganggap bacaan MT הֶעֵבריר (meski bukan textus receptus) perlu sebagai pengingat bagi

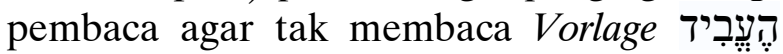
begitu saja memperbudak. Akan tetapi,

\footnotetext{
${ }^{51}$ Hoffmeier, "Egyptians," 270-271, 286.

${ }^{52}$ Speiser, Genesis, 353, "such censorious comments show little understanding of either history or literature."

53 Tak ditemukan TB "memperhamba" atau "menghamba", tetapi banyak TB "menjadi hamba" (Kej. 9:25), cukup sering "memperbudak" (Kej. 15:14), "diperbudak" (Kej. 15:13), "dijadikan budak" (Kej. 43:18), atau "menjadi budak" (Kej. 44:9).
} 
mengingat TB "diperhambakan" masih dibaca sebagai sinonim "diperbudak," terjemahan "dipekerjakan" perlu menjadi pertimbangan, seperti yang sudah dijelaskan di atas. Nuansa kata dalam terjemahan Alkitab memang sebuah alasan untuk begitu banyak versi terjemahan Alkitab. ${ }^{54}$ Selain itu, juga perlu dipertimbangkan konteks standar moral Timur Tengah kuno (bukan kritik nabi terhadap kekuasaan yang menindas), sebagaimana telah disimpulkan dengan baik oleh Nahum Sarna.

Joseph's actions cannot be measured by the moral standards that the Hebrew Bible, especially the prophetic tradition, has inculcated in Western civilization. Rather, they must be judged in the context of the ancient Near Eastern world, by whose norms Joseph emerges here as a highly admirable model of a shrewd successful administrator. ${ }^{55}$

\section{KESIMPULAN}

Dari hasil kajian tekstual dan tafsir di atas, tampaklah bahwa tak terbukti Yusuf memperhamba (memperbudak) rakyat Mesir, sebagaimana terindikasi dari kebanyakan terjemahan untuk Kejadian 47:21 (merujuk teks Yunani). Teks Ibrani memang memberikan bacaan berbeda tetapi sebaiknya bukan sebagai alternatif terjemahan, melainkan sebagai penanda agar teks tak dimaknai sebagai perbudakan. Tugas para penerjemah Alkitablah untuk membahasakannya setepat mungkin dan sebisanya mencegah ambiguitas tafsir yang tak perlu.

Alih-alih memperbudak, Yusuf justru merumuskan suatu kebijakan agraria Mesir dalam konteks besar narasi Yusuf sebagai pemelihara hidup orang banyak. Narasi itu memang memperlihatkan rakyat Mesir kehilangan hak

\footnotetext{
${ }^{54}$ Sakae Kubo \& Walter F. Specht, So Many Versions?: Twentieth-century English Versions of the Bible (Grand Rapids: Zondervan, 1983), 18, "No translation of the Bible can ever be considered final. Translations must keep pace
}

kepemilikan tanah, tetapi mereka dipekerjakan oleh istana dalam skema bagi hasil yang saling menguntungkan dan mereka tak terpisah dari tanah warisan. Demikian kontribusi kajian artikel ini untuk terjemahan Alkitab Indonesia dan tafsir ulang sosok Yusuf dalam kesesuaian dengan realitas naratif.

\section{PERNYATAAN PENULIS}

\section{Kontribusi dan Tanggung Jawab Penulis}

Penulis menyatakan telah memberikan kontribusi substansial untuk perancangan dan penulisan hasil penelitian. Penulis bertanggung jawab atas analisis, interpretasi dan diskusi hasil penelitian. Penulis telah membaca dan menyetujui naskah akhir.

\section{Konflik Kepentingan}

Penulis menyatakan tidak memiliki konflik kepentingan apa pun yang dapat memengaruhinya dalam penulisan artikel ini.

\section{DAFTAR KEPUSTAKAAN}

Brueggemann, Walter. Genesis. Interpretation. Atlanta: John Knox, 1982.

Calvin, John. Commentaries on the Book of Genesis. Vol. 2. Terj. John King. Grand Rapids: Eerdmans, 1948.

Cha, Kilnam. "Joseph's Unjust Economic Policies in Genesis 47:13-26." Leaven 24 (2016): 190-193.

Coats, George W. Genesis: With an Introduction to Narrative Literature. The Forms of the Old Testament Literature Vol. 1. Grand Rapids: Eerdmans, 1983.

Fretheim, Terence E. "Genesis" dalam The New Interpreter's Bible, Vol. 1: Genesis to Leviticus, diedit oleh Leander E. Keck. Nashville: Abingdon, 1994.

with the growth in biblical scholarship and the changes in language."

${ }^{55}$ Sarna, Genesis, 322-323. 
Fuller, David J. An Examination of Joseph's Enslavement of the Egyptians in Gen 47:13-26 in light of Relevant Slavery Texts across the Tanakh. Tesis, McMaster Divinity College, 2013.

Hamilton, Victor P. The Book of Genesis: Chapters 18-50. The New International Commentary on the Old Testament. Grand Rapids: Eerdmans, 1995.

Hoffmeier, James K. "Egyptians." Dalam Alfred J. Hoerth, Gerald L. Mattingly, and Edwin M. Yamauchi, ed., Peoples of the Old Testament World, 251-290. Grand Rapids: Baker, 1994.

Keil, C.F. dan F. Delitzsch. The Pentateuch. Commentary on the Old Testament. Vol. 1. 1885. Reprint, Peabody: Hendrickson, 2006.

Kubo, Sakae dan Walter F. Specht. So Many Versions?: Twentieth-century English Versions of the Bible. Ed. rev. Grand Rapids: Zondervan, 1983.

Lempp, Walter. Kejadian 37:1-50:26. Tafsiran Alkitab. Jakarta: Gunung Mulia, 1977.

Lust, Johan, Erik Eynikel, dan Katrin Hauspie, eds. Greek-English Lexicon of the Septuagint. Ed. rev. Stuttgart: Deutsche Bibelgesellschaft, 2003.

McCarter, P. Kyle. Textual Criticism: Recovering the Text of the Hebrew Bible. Guides to Biblical Scholarship. Philadelphia: Fortress, 1986.

Mendelsohn, Isaac. "Dream." Dalam The Interpreter's Dictionary of the Bible. Vol. 1. Diedit oleh George A. Buttrick. New York: Abingdon, 1962.

Rad, Gerhard von. Genesis. Old Testament Library. Terj. John H. Marks. Philadelphia: Westminster, 1972.
Sarna, Nahum M. Genesis. JPS Torah Commentary. Philadelphia: The Jewish Publication Society, 1989.

Sheridan, Mark, ed. Genesis 12-50. Ancient Christian Commentary on Scripture: Old Testament. Vol. 2. Downers Grove: InterVarsity, 2002.

Skinner, John. Genesis. International Critical Commentary. Edinburgh: T\&T Clark, 1917.

Snell, Daniel C. Life in the Ancient Near East: 3100-332 BCE. New Haven: Yale University Press, 1997.

Speiser, E. A. Genesis. Anchor Bible Vol. 1. New York: Doubleday, 1962.

Strine, Casey A. "The Famine in the Land Was Severe: Environmentally Induced Involuntary Migration and the Joseph Narrative." Hebrew Studies 60 (2019): 5569. https://doi.org/10.1353/hbr.2019.0020.

Wenham, Gordon J. Genesis 16-50. Word Biblical Commentary 2. Waco: Word, 1994.

Westermann, Claus. Genesis 37-50. A Continental Commentary. Terj. John J. Scullion. Minneapolis: Augsburg, 1986.

Seters, John Van. Prologue to History: The Yahwist as Historian in Genesis. Louisville: Westminster John Knox, 1992.

Vaux, Roland de. Ancient Israel: Its Life and Institutions. Terj. John McHugh. Grand Rapids: Eerdmans, 1997.

Würthwein, Ernst. The Text of the Old Testament: An Introduction to the Biblia Hebraica. Terj. Erroll F. Rhodes. Ed. ke2. Grand Rapids: Eerdmans, 1995.

Youngblood, Ronald F. The Book of Genesis: An Introductory Commentary. Grand Rapids: Baker, 1991. 